TRIBUTE

\title{
Tribute to Evan Weissman on behalf of the Syracuse-Onondaga Food Systems Alliance
}

On behalf of the members of the Syracuse-Onondaga Food Systems Alliance by:

Maura Ackerman, ${ }^{\text {* }}$ Syracuse-Onondaga Food Systems Alliance

Mary Carney, ${ }^{\mathrm{b}}$ Independent Consultant

Brandy Colebrook, ${ }^{c}$ Refugee and Immigrant Self-Empowerment (RISE)

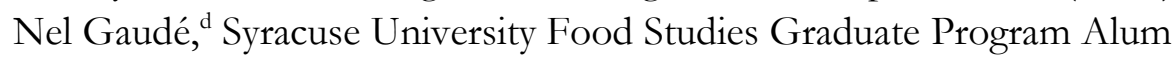

Elissa Johnson, ${ }^{\mathrm{e}}$ Science \& Ecology, PrattMWP

LaToya Jones, ${ }^{\mathrm{f}}$ Healthcare Education Project Syracuse

David Knapp, ${ }^{g}$ Onondaga County Legislature

Jessi Lyons, ${ }^{\text {h }}$ Brady Farm

Peter Ricardo, ${ }^{\mathrm{i}}$ Food Bank of Central New York

Jonnell Robinson, 'Syracuse University Department of Geography and the Environment

Rachel Viens, ${ }^{k}$ Syracuse City School District Food \& Nutrition Services

Curtis Waterman, ${ }^{1}$ Onondaga Nation Farm

Submitted December 29, 2020 / Published online September 16, 2021

Citation: Ackerman, M., Carney, M., Colebrook, B., Gaudé, N., Johnson, E., Jones, L., Knapp, D., Lyons, J., Ricardo, P., Robinson, J., Viens, R., \& Waterman, C. (2021). Tribute to Evan Weissman on behalf of the Syracuse-Onondaga Food Systems Alliance. Journal of Agriculture, Food Systems, and Community Development, 10(4), 27-28. https://doi.org/10.5304/jafscd.2021.104.021

Copyright (C) 2021 by the Authors. Published by the Lyson Center for Civic Agriculture and Food Systems. Open access under CC-BY license.

$\mathrm{P}$ rofessor Evan Weissman was a driving force behind the formation of the Syracuse-Onondaga Food Systems Alliance (SOFSA) - a newly established food policy council based in the city to which he was so deeply committed. Evan was a tireless advocate for the need for coordinated efforts across the food system in order to achieve the transformational change he saw as foundational to achieving justice

a* Corresponding author: Maura Ackerman, Facilitator, Syracuse-Onondaga Food Systems Alliance; 168 Westminster Avenue; Syracuse, NY 13210 USA; +1-315-552-0471; maura@syrfoodalliance.org

Mary Carney, Independent Consultant

Brandy Colebrook, Agriculture Programs Director, Refugee and Immigrant Self-Empowerment (RISE)

Nel Gaudé, Alum, Syracuse University Department of Nutrition and Food Studies

Elissa Johnson, Adjunct Professor of Science \& Ecology, PrattMWP

LaToya Jones, Regional Healthcare Organizer, Healthcare Education Project Syracuse

David Knapp, Chair, Onondaga County Legislature

Jessi Lyons, Coordinator, Brady Farm

Peter Ricardo, Product Donations Manager, Food Bank of Central New York

Jonnell Robinson, Associate Professor, Syracuse University Department of Geography and the Environment

Rachel Viens, Director of Food \& Nutrition Services, Syracuse City School District

Curtis Waterman, Hunter-Gatherer, Onondaga Nation Farm 
for all. SOFSA's work will be just one of the many pieces of the enduring legacy of the life he lived and the values he held so deeply.

By building a robust network of partners across sectors, SOFSA aims to strengthen our local food system so that it works for all people in our community. We believe that the health of our neighbors and our environment are deeply intertwined. In order to ensure that both can thrive, we must dismantle the structural systems that drain resources from our community and the land on which we depend. Yet to do this, we cannot operate in isolation. We must pool our collective wisdom and amplify existing assets to catalyze the change we seek.

On April 6, 2020, just days before his passing, Evan and his colleagues published a special commentary in the Syracuse Post Standard. The piece, entitled "From farm to factory to table, coronavirus pandemic challenges US food system," articulated the ways our current food system has been stressed by the ongoing pandemic and called out the importance of food councils in responding to these challenges in both the short and long terms (Bellows et al., 2020).

The COVID-19 pandemic lays bare the contradictions of the modern food system. We all now recognize - and have infinite memes celebrating - the critical social, economic and public health roles played by food supply chains and the workers, managers, business owners and firms that compose it and make it function. At the same time, the inequalities that define our food system are more apparent than ever: Workers in the food system are precarious, lack adequate pay and health benefits, and yet are asked to take risks to ensure food is available so we all can eat. ... Promoting and supporting organizations and efforts to develop and expand local and regional food systems and local food policy councils could enhance our response to future disasters and bring needed environmental, economic development and food security benefits to our region and the United States. (Bellows et al., 2020, para. 1 \& 5)

The stakes of our success or failure in our efforts to achieve food justice cannot be understated. We hold this knowledge closely each and every day as we pursue a vision for our community in which we all have the opportunity to thrive. Evan continuously imparted the awareness of this imperative for action in every aspect of his life and work.

This loss of Evan was sudden and tragic for everyone in our partnership and our community as a whole, causing far-reaching impacts to the many lives he touched. And yet, it has also translated into the fortified resolve to carry on Evan's unwavering dedication, striving to ensure equitable access to food in Syracuse and throughout Central New York. We have collectively committed-perhaps even more passionately now- to our work together and to carrying on in Evan's honor. We will be forever grateful for the ways we learned and grew as a result of his wisdom, the strength of his character, and his unwavering commitment to our shared ideals.

\section{Reference}

Bellows, A., Welsh, R., Weissman, E., Kiernan, M., Brann, L., Bruening, K. S., Beckwith, N. M., Charles, C., Johnson, E., Minkoff-Zern, L.-A., Horacek, T., Raj, S., Redmond, J., Rindfuss, N., Uzcategui, J., Voss, M., \& Wilkins, J. (2020, April 6). From farm to factory to table, coronavirus pandemic challenges US food system [Commentary]. syracuse.com / The Post Standard. https://www.syracuse.com/opinion/2020/04/from-farm-to-factory-to-table-coronaviruspandemic-challenges-us-food-system-commentary.html 